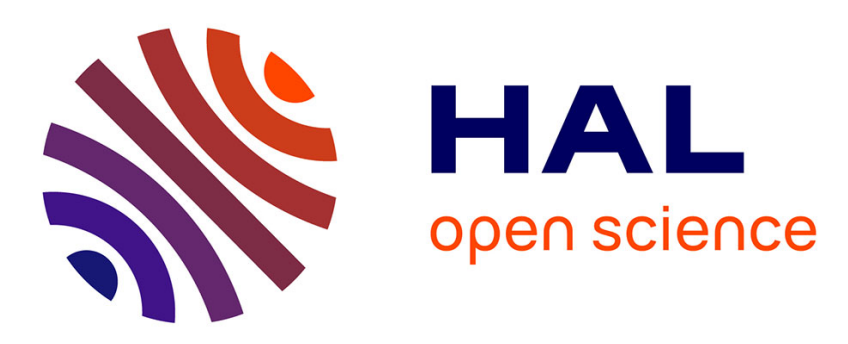

\title{
How does iron storage protein ferritin interact with plutonium (and thorium)?
}

Cyril Zurita, Satorou Tsushima, Carole Bresson, Marta Garcia Cortes, Pier Lorenzo Solari, Gaëlle Creff, Christophe den Auwer

\section{To cite this version:}

Cyril Zurita, Satorou Tsushima, Carole Bresson, Marta Garcia Cortes, Pier Lorenzo Solari, et al.. How does iron storage protein ferritin interact with plutonium (and thorium)?. Chemistry - A European Journal, 2020, pp.Chem. Eur. J. 10.1002/chem.202003653. 10.1002/chem.202003653 . cea-02995304

\section{HAL Id: cea-02995304 https://hal-cea.archives-ouvertes.fr/cea-02995304}

Submitted on 9 Nov 2020

HAL is a multi-disciplinary open access archive for the deposit and dissemination of scientific research documents, whether they are published or not. The documents may come from teaching and research institutions in France or abroad, or from public or private research centers.
L'archive ouverte pluridisciplinaire HAL, est destinée au dépôt et à la diffusion de documents scientifiques de niveau recherche, publiés ou non, émanant des établissements d'enseignement et de recherche français ou étrangers, des laboratoires publics ou privés. 


\section{Chemistry \\ Chemistry Europe}

A European Journal

European Chemical Societies Publishing

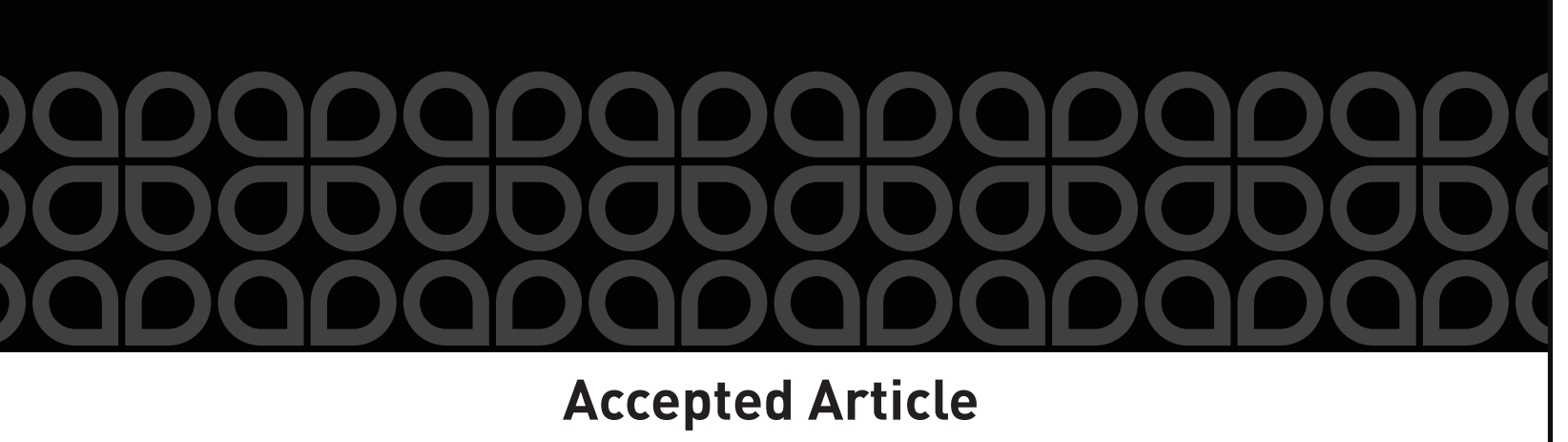

Title: How does iron storage protein ferritin interact with plutonium (and thorium)?

Authors: Cyril Zurita, Satoru Tsushima, Carole Bresson, Marta Garcia Cortes, Pier Lorenzo Solari, Aurélie Jeanson, Gaëlle Creff, and Christophe den Auwer

This manuscript has been accepted after peer review and appears as an Accepted Article online prior to editing, proofing, and formal publication of the final Version of Record (VoR). This work is currently citable by using the Digital Object Identifier (DOI) given below. The VoR will be published online in Early View as soon as possible and may be different to this Accepted Article as a result of editing. Readers should obtain the VoR from the journal website shown below when it is published to ensure accuracy of information. The authors are responsible for the content of this Accepted Article.

To be cited as: Chem. Eur. J. 10.1002/chem.202003653

Link to VoR: https://doi.org/10.1002/chem.202003653 
WILEY-VCH

\title{
How does iron storage protein ferritin interact with plutonium (and thorium)?
}

\author{
Cyril Zurita ${ }^{[a]}$, Satoru Tsushima ${ }^{[b, e]}$, Carole Bresson ${ }^{[c]}$, Marta Garcia Cortes ${ }^{[c]}$, Pier Lorenzo Solari ${ }^{[d]}$, \\ Aurélie Jeanson $^{[a]}$, Gaëlle Creff ${ }^{[a]}$, Christophe Den Auwer ${ }^{*[a]}$
}

[a] Cyril Zurita, Gaëlle Creff, Christophe Den Auwer,

Université Côte d'Azur, CNRS, Institut de Chimie de Nice,

06108 Nice, France

E-mail: christophe.denauwer@univ-cotedazur.fr ; gaelle.creff@univ-cotedazur.fr

[b] Pr. Satoru Tsushima

Institute of Resource Ecology, Helmholtz-Zentrum Dresden-Rossendorf (HZDR),

01328 Dresden, Germany.

E-mail: s.tsushima@hzdr.de

[c] Carole Bresson, Marta Garcia Cortes,

Université Paris-Saclay, CEA, Service d'Etudes Analytiques et de Réactivité des Surfaces,

91191, Gif-sur-Yvette, France

Email: carole.bresson@cea.fr ; marta.garcia-cortes@cea.fr

[d] Pier Lorenzo Solari

Synchrotron SOLEIL, L'Orme des Merisiers, Saint Aubin,

F91192 Gif-sur-Yvette, Cedex, France

E-mail: pier-lorenzo.solari@synchrotron-soleil.fr

[e] World Research Hub Initiative (WRHI), Institute of Innovative Research, Tokyo Institute of Technology, Meguro, 152-8550, Tokyo, Japan

Supporting information for this article is given via a link at the end of the document

\begin{abstract}
The impact of the contamination of living organisms by actinide elements has been a constant subject of attention since the 1950 s. But to date still little is understood. Ferritin is the major storage and regulation protein of iron in many organisms, it consists of a protein ring and a ferrihydric core at the center. This work sheds light on the interactions of early actinides (Th, Pu) at oxidation state +IV with ferritin and its ability to store those elements at physiological $\mathrm{pH}$ compared to Fe.

The Ferritin - thorium load curve suggests that Th(IV) saturates the protein (2840 Th atoms per ferritin) in a similar way that Fe does on the protein ring. Complementary spectroscopic techniques (Spectrophotometry, Infrared Spectroscopy and X-ray Absorption Spectroscopy) were combined with Molecular Dynamics to provide a structural model of the interaction of Th(IV) and $\mathrm{Pu}(\mathrm{IV})$ with ferritin. Comparison of spectroscopic data together with MD calculations suggests that Th(IV) and Pu(IV) are complexed mainly on the protein ring and not on the ferrihydric core. Indeed from XAS data, there is no evidence of $\mathrm{Fe}$ neighbors in the Th and Pu environments. On the other hand, carboxylates from amino acids of the protein ring and a possible additional carbonate anion are shaping the cation coordination spheres. This thorough description from a molecular view point of $\mathrm{Th}(\mathrm{IV})$ and $\mathrm{Pu}(\mathrm{IV})$ interaction with ferritin, an essential iron storage protein, is a cornerstone in comprehensive nuclear toxicology.
\end{abstract}

\section{Introduction}

Nuclear fission was first discovered in 1942. Since then, the nuclear industry has been rapidly developing in the civil and military sectors with applications in both energy production and defense. This has brought new geostrategic, geopolitical and environmental challenges and has raised a multitude of questions concerning the impact on security, on the environment, the biosphere and ultimately on the human population. During this time, public attitudes toward the use of nuclear energy have also evolved as awareness has grown over the potential dangers of nuclear contamination. The main hazards are associated with actinide elements and some fission products (elements emitting mainly alpha and/or beta particles associated or not with gamma rays) which can be both chemically and radiologically toxic when ingested by humans or animals. ${ }^{1}$ The heaviest of those elements have no known biological function and, in addition to their chemical toxicity, are also capable of producing high levels of localized radiation damage. ${ }^{2}$ In-depth studies of the biodistribution and bio-kinetics of actinides are essential for understanding its in vivo behavior and for documenting its biochemical toxicity. However, knowledge relative to actinide transportation mechanisms, formation of complexes and the accumulation of these elements in various biological compartments, at a molecular level, is still patchy and unclear. ${ }^{3}$ Our focus is on plutonium $(\mathrm{Pu})$ because of its key role in the nuclear cycle and its emblematic position in the public perception of nuclear risk. In the current geopolitical and technological context, the probability of an accidental release of $\mathrm{Pu}$ into the environment is very low but the consequences, if it were to occur, would be disastrous. Pu itself is both a strong chemical and radiotoxic element and is strongly retained by organisms. ${ }^{4}$ Consequently, the uptake of Pu can present considerable health risks. In mammals, Pu migrates to the liver and skeleton, where it can remain for decades. ${ }^{2}$ Early studies by Durbin have shown that rat liver (and feces) accumulate about $30 \%$ of initial $\mathrm{Pu}(\mathrm{IV}$ ) dose after few 1-8 days. ${ }^{5}$ Further studies on rats and mice (injection of $\mathrm{Pu}(\mathrm{IV})$ citrate, intravenously) propose retention figures of $\mathrm{Pu}$ in the skeleton and liver equal to 7 and $5 \%$ respectively after $1 \mathrm{~h} ; 27 \%$ and $7 \%$ respectively after $24 \mathrm{~h} .{ }^{6}$. More recently, Ansoborlo et al reported several figures and underlined the importance of the injected chemical form, speciation (for $\mathrm{Pu}$ 
citrate, after 1 day, about $10 \%$ of $\mathrm{Pu}$ is retained in rat liver). ${ }^{7,8}$ Overall, significant discrepancies in the data reflect the importance of speciation dans kinetics in distribution results but in any case liver is a significant target organ of soluble plutonium. ${ }^{9,10}$

In vivo $\mathrm{Pu}$ is mainly present at oxidation state +IV with the following chemical properties ${ }^{11}$ : hard acid on Pearson's scale, large coordination numbers (8-12), ${ }^{12}$ and very high hydrolysis propensity. Finally, although $\mathrm{Pu}(\mathrm{IV})$ chemistry bears little resemblance to that of $\mathrm{Fe}(\mathrm{III})$ it has been suggested that their biological reactivities are comparable to some extent. ${ }^{13}$ In mammals for instance, the majority of $\mathrm{Fe}$ is incorporated into the structure of hemoglobin where it serves as a binding site for oxygen transport. The remainder of the $\mathrm{Fe}$ is transported in the blood by bio-ligands such as proteins to various organs. ${ }^{14}$ Once it has passed the cell barrier, iron can be used by mitochondria and stored in the ferritin protein, which allows its regulation in the body. ${ }^{15}$

In vivo, specifically in mammals, it has been shown that transferrin involved in the iron cycle is a possible target of $\mathrm{Pu}{ }^{16}$ $\mathrm{Pu}$ is believed to be transported in the blood and into the cells by transferrin. ${ }^{17,18}$ Once in contact with the cell, it can pass the cell barrier (endocytosis) and thus end up in the cell. However, the specific pathways at the molecular level that Pu uses to locate and enter into cells have never been fully understood. ${ }^{19}$ In liver cells more specifically, interactions between $\mathrm{Pu}$ and ferritin have been mentioned but not characterized. ${ }^{20,21,22}$ In rat's liver the transfer of plutonium from transferrin to ferritin has been reported to be similar as iron. ${ }^{20}$ In beagles livers injected with $\mathrm{Pu}(\mathrm{IV})$ citrate, most of soluble Pu has been found associated with ferritin in the cytosol fraction and in mitochondria. ${ }^{21}$ This seems to draw a paralell between plutonium and iron incorporation into hepatic cells involving ferritin. ${ }^{23}$ In the longer term, such parallel could drive the release of $\mathrm{Pu}$ into the haptic cell and make it available for chronic contamination.

The ferritin protein can store up to 4500 iron atoms as an iron oxohydroxide core. ${ }^{24}$ It is also capable of releasing iron, which is stored in a controlled manner. ${ }^{25-26}$ It is an oligomeric protein consisting of 24 subunits of mass $474 \mathrm{kDa}$, presenting a quaternary structure (heavy $\mathrm{H}$ and light $\mathrm{L}$ subunits of $21 \mathrm{kDa}$ and $19 \mathrm{kDa}$, respectively). ${ }^{27}$ Ferritin has a hollow spherical conformation with an outer diameter of $12 \mathrm{~nm}$ and a cavity of 8 $\mathrm{nm}^{28}$. Channels between the subunits form an iron-protein interaction pathway from the surface of the protein to its iron core. $\mathrm{Fe}$ (essentially $\mathrm{Fe}^{2+}$ ) once interacting with the protein, will move to its center to accumulate and form a stable ferric oxyhydroxide core called ferrihydrite $(\mathrm{Fe}(\mathrm{III}))$. The ferritin contained in the liver is composed mainly of the $L$ subunit (about $90 \%$ ). Conversely, the heart and kidneys are composed mainly of the $\mathrm{H}$ subunit. ${ }^{29-30}$ Ferritin is able to store exogenous metals, many +II cations: $\mathrm{Cu}^{2+}$, $\mathrm{Co}^{2+}, \mathrm{Zn}^{2+}, \mathrm{Mn}^{2+}, \mathrm{Pd}^{2+}$ and $\mathrm{Mg}^{2+} \cdot{ }^{31}$ While the $\mathrm{H}$ subunit is mainly associated with RedOx processes (oxidation of $\mathrm{Fe}(\mathrm{II})$ into $\mathrm{Fe}(\mathrm{III})$ ), the $L$ subunit is devoted to Fe storage mechanisms. ${ }^{32}$

In this report we describe with a methodology that we have developed the mechanisms of ferritin-plutonium and ferritinthorium interactions with $L$ subunit. ${ }^{33}{ }^{232} \mathrm{Th}(\mathrm{IV})$ is used for some of the following experiments as a chemical surrogate of ${ }^{239} \mathrm{Pu}(\mathrm{IV})$ because the massic activity of the latter makes it very difficult to manipulate. To accomplish this, we utilized an original tool box made of analytical, spectroscopic and macromolecular model tools. At first, a ferritin-Th response curve with ICP-MS
(Inductively Coupled Plasma - Mass Spectrometry) was performed. Then the Th and Pu local environments when bound to ferritin were explored with XAS (X-ray Absorption Spectroscopy) complemented with IR (Infra Red) and spectrophotometry. A macromolecular model realized by MD (Molecular Dynamic) calculations allowed us to pinpoint the amino acids involved in this interaction. Based on these data, we were able to formulate a hypothesis regarding the interaction mechanisms between $\mathrm{Pu} / \mathrm{Th}$ and ferritin.

\section{Results and Discussion}

To avoid hydrolysis at physiological $\mathrm{pH}, \mathrm{Th}(\mathrm{IV})$ and $\mathrm{Pu}(\mathrm{IV})$ were protected by carbonate anions who are found in serum at $22 \mathrm{mM}$ to $28 \mathrm{mM}$ level. ${ }^{34}$ The limit complexes $\mathrm{M}^{\mathrm{IV}}\left(\mathrm{CO}_{3}\right)_{5}{ }^{6-}(\mathrm{M}=\mathrm{Th}, \mathrm{Pu})$ have been prepared and used as stock An solutions.

\section{Ferritin characterization}

Ferritin is composed of two types of subunits ( $L$ and $H$ subunits) for which the amino acid sequence is listed in Table S1 of SI. Ferritin (horse spleen) was purchased from Sigma-Aldrich. It is composed of $90 \% \mathrm{~L}$ subunit and $10 \% \mathrm{H}$ subunit. Because Ferritin proteins are characterized by their Fe content, the Fe elemental content was quantified by ICP-MS/MS in our stock solution (noted stock-F) after a dialysis step (see experimental section). The maximum storage capacity is estimated in the literature around $4500 \mathrm{Fe}$ atoms total. Previous studies have determined that the ferrihydrite core of ferritin can contain up to about 1800 $\mathrm{Fe}$ atoms and the average loading capacity of the protein ring is of the order of $2800 \mathrm{Fe}$ atoms (total $=4500$ ). ${ }^{35-36}$ In stock-F, the amount of $\mathrm{Fe}$ atoms has been determined equal to 517 (Table $\mathrm{S} 2$ of SI). Iron contained in our F-stock represents approximately $11 \%$ of the maximum storage capacity.

\section{Ferritin - plutonium interaction, spectrophotometry}

The complexation of $\mathrm{Pu}(\mathrm{IV})$ with stock-F has been monitored by spectrophotometry (Figure $\mathrm{S} 1$ of $\mathrm{SI}$ ) and compared to the spectrum of the $\mathrm{Pu}(\mathrm{IV})$ carbonate complex $\mathrm{Pu}\left(\mathrm{CO}_{3}\right)_{5}{ }^{6-}$. The band at $486 \mathrm{~nm}$, is characteristic of $\mathrm{Pu}\left(\mathrm{CO}_{3}\right) 5^{6-}$ with extinction coefficient $\varepsilon=66 \mathrm{~L} \cdot \mathrm{cm}^{-1} \cdot \mathrm{mol}^{-1}{ }^{37}$ The spectrum of F-Pu (with F/Pu ratio equal to $1 / 2780$ ), taken 24 hours after mixing (red line) is characterized by a drastic decrease in the absorbance compared to the carbonate and a splitting of the band centered at $486 \mathrm{~nm}$ in two distinct bands at 484 and $487 \mathrm{~nm}$. This change is in agreement with a displacement of carbonate anions in the $\mathrm{Pu}$ coordination sphere and consequently with the formation of a plutonium-ferritin complex subsequently noted $\mathrm{Pu}-\mathrm{F}$ complex. After the successive addition of $3 \mathrm{M}$ carbonate solution, this double band increases again and evolves towards the band associated with pure $\mathrm{Pu}\left(\mathrm{CO}_{3}\right) 5^{6-}$, meaning that complexation is reversible in the presence of a large excess of carbonate (as discussed in the last section).

In order to further characterize the $\mathrm{F}$ complexation capacity, a load curve was measured and is discussed in the next section.

\section{Ferritin-Thorium load curve}

Because of radioprotection safety, a Pu(IV) load curve could not be recorded in our laboratory. Taking advantage of the relative chemical analogy between Th(IV) and Pu(IV), only the Th(IV) load curve was performed. 


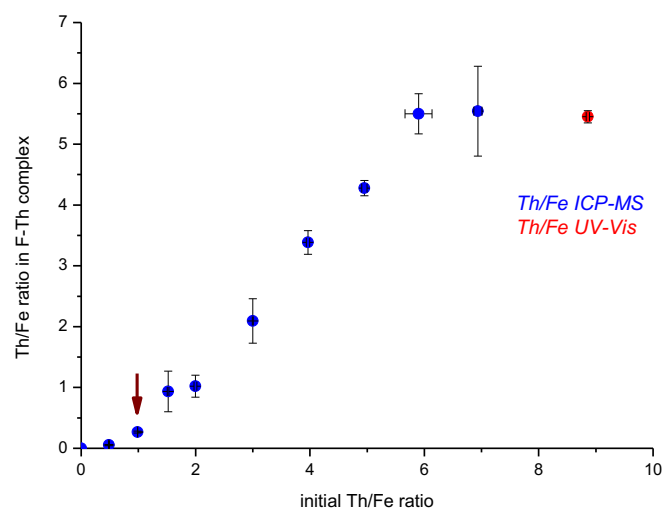

Figure 1. F-Th load curve. Ferritin in MES-NaCl buffer medium (50 $m M-150 \mathrm{mM}$ ) at $\mathrm{pH}=7.5$. Thorium is brought in as thorium carbonate. Samples were prepared in triplicate. Average Th/Fe ratio values obtained by ICP-MS/MS (blue dots) and by UV-Vis (red dot). The last point (red dot) allows to confirm the plateau of the curve. $Y$ error bars correspond to $1 S D, X$-error bars. atoms that has been reported in the literature to be bound to the protein ring. According to this hypothesis, Ferritin would therefore be able to saturate its protein ring with Th in the same way as it does naturally with iron.

\section{Ferritin-Th Infrared spectrum}

In order to obtain an initial image on the chemical environment of Th after complexation, an Infrared study was carried out (for the same reason as above, only Th was studied in this section). In Figure $\mathrm{S} 2$ of $\mathrm{SI}$, the reference spectrum of $\mathrm{Th}\left(\mathrm{CO}_{3}\right)_{5}{ }^{6-}$ (blue line) is compared to that of stock-F (black line) and to that of the F-Th complex (red line). The F-Th complex was micro-filtrated at $30 \mathrm{kDa}$ and then washed to remove the excess of Th carbonate that did not interact with the protein $(\mathrm{Th} / \mathrm{Fe}$ ratio $=5.4)$. The $\mathrm{Th}\left(\mathrm{CO}_{3}\right)_{5}{ }^{6-}$ spectrum highlights the presence of symmetric and antisymmetric characteristic bands of the $v_{3}$ carbonates at $1606 \mathrm{~cm}^{-1}$ and $1360 \mathrm{~cm}^{-1}$ respectively ${ }^{38,39}$ in the bidentate mode ${ }^{40,41}$. The spectrum of stock- $F$ (black line) shows the amide bands I and II at $1651 \mathrm{~cm}^{-1}$ and $1549 \mathrm{~cm}^{-1}$ respectively. The spectrum of the F-Th complex (red line) also shows the amide

\begin{tabular}{|c|c|c|c|c|}
\hline Sample & O/N first shell & C shell & $\begin{array}{c}\mathrm{S}_{0}^{2} \\
\Delta \mathrm{EO}(\mathrm{eV})\end{array}$ & $\begin{array}{l}\text { Q factor } \\
\text { R-factor }\end{array}$ \\
\hline $\mathrm{Pu}\left(\mathrm{CO}_{3}\right)_{5}^{6-}$ & $\begin{array}{c}10.2(4) \mathrm{O} \text { at } 2.44(2) \AA \\
\sigma^{2}=0.006 \AA^{2}\end{array}$ & $\begin{array}{c}5.1(4) \mathrm{C} \text { at } 2.88(1) \AA \\
\sigma^{2}=0.008 \AA^{2}\end{array}$ & $\begin{array}{c}1.0 \\
6.54\end{array}$ & $\begin{array}{c}38 \\
3.1 \%\end{array}$ \\
\hline $\mathrm{F}-\mathrm{Pu}$ & $\begin{array}{c}100 \text { (fixed) at } 2.39(5) \AA \\
\sigma^{2}=0.007 \AA^{2}\end{array}$ & $\begin{array}{c}5.2(20) C \text { at } 3.34(4) \AA \\
\sigma^{2}=0.007 \AA^{2}\end{array}$ & $\begin{array}{c}1.0 \\
6.26\end{array}$ & $\begin{array}{c}32 \\
2.2 \%\end{array}$ \\
\hline $\operatorname{Th}\left(\mathrm{CO}_{3}\right)_{5}^{6-}$ & $\begin{array}{c}10.8(4) \mathrm{O} \text { at } 2.50(8) \AA \\
\sigma^{2}=0.007 \AA^{2}\end{array}$ & $\begin{array}{c}5.4(4) C \text { at } 2.96(9) \AA \\
\sigma^{2}=0.014 \AA^{2}\end{array}$ & $\begin{array}{c}1.0 \\
7.07\end{array}$ & $\begin{array}{c}39 \\
2.9 \%\end{array}$ \\
\hline F-Th & $\begin{array}{c}100 \text { (fixed) at } 2.44(6) \AA \\
\sigma^{2}=0.007 \AA^{2}\end{array}$ & $\begin{array}{c}5.1(22) C \text { at } 3.56(26) \\
\AA \\
\sigma^{2}=0.005 \AA^{2}\end{array}$ & $\begin{array}{c}1.0 \\
6.52\end{array}$ & $\begin{array}{c}14 \\
2.1 \%\end{array}$ \\
\hline
\end{tabular}

Table 1. Best fit structural parameters obtained from EXAFS data fitting. For F-Pu and F-Th, figures in italics have been fixed. $\sigma^{2}$ is the Debye Waller factor of the considered scattering path. $S_{0}{ }^{2}$ is the global amplitude factor, $\mathrm{e}_{0}$ is the energy threshold, $R_{\text {factor }}$ is the agreement factor of the fit in \% and QF is the quality factor (reduced $\mathrm{CH}^{2}$ ) of the fit. Uncertainties given in bracket are related to the last digit.

The load curve is a titration of stock- $F$ with an increasing amount of $\mathrm{Th}\left(\mathrm{CO}_{3}\right) 5^{6-}$ solution in MES- $\mathrm{NaCl}$ buffer $(50 \mathrm{mM}-150 \mathrm{mM})$ at physiological $\mathrm{pH}(7.4)$. It was obtained with micro-filtration at 30 $\mathrm{kDa}$ (see experimental section and Table S3 of SI). The quantity of Th bound to $F$ was measured in the filter with ICP-MS/MS (blue dots) and UV-Vis (red dot). The load curve presented in Figure 1 is expressed as atomic $\mathrm{Th} / \mathrm{Fe}$ ratio on both axes and was carried out up to a maximal ratio of F/Th equal to $1 / 4500$ (corresponding to $\mathrm{Th} / \mathrm{Fe}=8.7)$. In the first part of this curve, between $\mathrm{Th} / \mathrm{Fe}$ equal to 0 to 6 , the capacity of the protein to store Th increases linearly. After $\mathrm{Th} / \mathrm{Fe}$ ratio reaches 6 , a plateau is observed. This plateau corresponds to a Th/Fe ratio in the complex equal to 5.5. Note that according to the characterization of our stock-F after dialysis, 517 iron atoms are already present. Therefore, if no Fe atom is released during Th complexation, this corresponds to a number of about 2840 thorium atoms bound to one $\mathrm{F}$ (Table S4 of SI). This number corresponds to the approximate number of $\mathrm{Fe}$ bands I and II at $1651 \mathrm{~cm}^{-1}$ and $1549 \mathrm{~cm}^{-1}$ respectively but also a band at $1361 \mathrm{~cm}^{-1}$ characteristic of the $\mathrm{v}_{3}$ carbonate antisymmetric band that overlaps with the previous bands (the two spectra of stock-F and F-Th have been normalized to the amide band I at $\left.1651 \mathrm{~cm}^{-1}\right)$. There is a decrease in these two bands compared to those of stock- $F$ (confirmed on the subtraction spectrum of \{stock-F - F-Th\}, green line). These results suggest the presence of at least one bidentate carbonate in F-Th complex.

\section{Ferritin-Th and Ferritin-Pu local environment}

To pinpoint the complexation site(s) of Th/Pu in the protein even further, XAS analyses of the local environment of Th and $\mathrm{Pu}$ in F-Th and F-Pu complexes were performed with F/Pu ratio equal to $1 / 550$ (corresponding to a incubation $\mathrm{Pu} / \mathrm{Fe}$ ratio equal to 1.1 ) and $F / T h$ ratio equal to $1 / 1973$ (corresponding to an incubation $\mathrm{Th} / \mathrm{Fe}$ ratio equal to 3.8). This ratio is shown by an arrow on Figure 1 as an indication. 
First, possible modifications of the protein iron core after complexation with Th were investigated measuring the protein XANES signal at the Fe K edge (similar XANES with F-Pu sample has not been realized). The XANES spectrum of F-Th shown in Figure S3ab of SI shows no difference to that of stock-F. Furthermore, a comparison was made with reference spectra of $\mathrm{Fe}(\mathrm{II})$ and $\mathrm{Fe}(\mathrm{III})$. Normalized absorption spectra together with first derivatives clearly show that both aspects of F-Th and Stock $\mathrm{F}$ are identical and correspond to the Fe(III) species. This is the natural storage oxidation degree of iron inside the ferritin core. A clear modification of Fe K edge XANES would imply that most Fe environments would be affected by the presence of Th atoms. The expected Th/Fe ratio is close enough to unity $(0.5$ from Figure 1) in our conditions to assume that in absence of Fe K edge XANES modification, most $F e$ atoms are located away from the Th complexation sites (away meaning further than 4-5 $\AA$ from the XAS point of view). In conclusion, it can be assumed that most Th atoms are not complexed on the ferrihydrite surface but on the protein ring.

In order to verify this assumption and complement the picture of the Th/Pu complexation sites, molecular dynamics models of the interaction of $\mathrm{Pu}$ with $\mathrm{F}$ were combined with the EXAFS measurements.

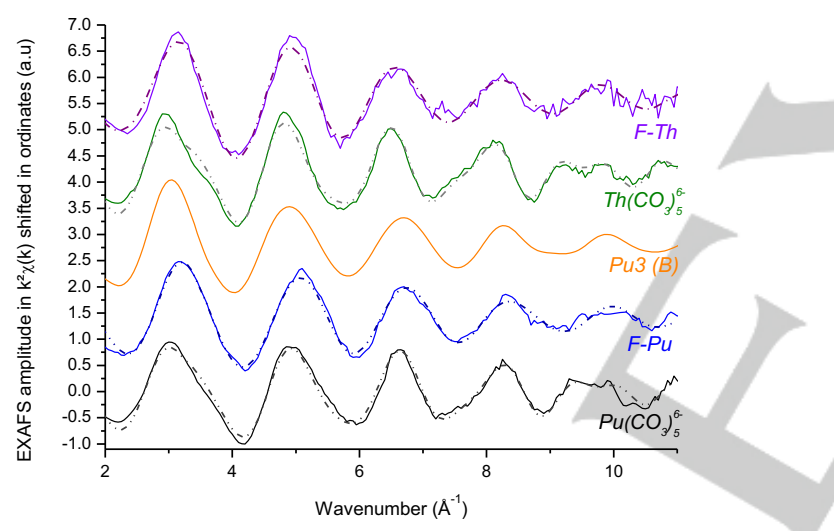

Figure 2. Th/Pu LIII edge experimental EXAFS spectra of F-Th (violet), $\mathrm{Th}\left(\mathrm{CO}_{3}\right)_{5} 5^{6-}$ (green), F-Pu (blue) and $\mathrm{Pu}\left(\mathrm{CO}_{3}\right)_{5} 5^{6-}$ (black). Fits are shown in dotted line. The orange line $(P u 3(B))$ corresponds to the simulation of the Pu site obtained from $M D$ representing the ternary complex (protein, carbonate, water).

Figure 2 compares the experimental EXAFS spectra of Th-F, $\mathrm{Th}\left(\mathrm{CO}_{3}\right)_{5}^{6-}, \mathrm{F}-\mathrm{Pu}$ and $\mathrm{Pu}\left(\mathrm{CO}_{3}\right)_{5}^{6-}$. When comparing the EXAFS spectra of $\mathrm{Th}\left(\mathrm{CO}_{3}\right)_{5}{ }^{6-}$ with that of $\mathrm{F}-\mathrm{Th}$ on the one hand and of $\mathrm{Pu}\left(\mathrm{CO}_{3}\right) 5^{6-}$ with that of $\mathrm{F}-\mathrm{Pu}$ on the other hand, significant differences appear. A shift in low $\mathrm{k}$ values and a modification of the wave shape are visible in Figure S4 (derivative of the EXAFS signal) between 2 and $4 \AA^{-1}$ between F-An and $A n^{\mathrm{IV}}\left(\mathrm{CO}_{3}\right)_{5}^{6-}(\mathrm{An}$ $=\mathrm{Th}, \mathrm{Pu})$. This is a qualitative indication that the environment around the actinide is different in the carbonate and the ferritin complexes. Best fit parameters of $\mathrm{An}^{\mathrm{IV}}\left(\mathrm{CO}_{3}\right)_{5}{ }^{6-}$ have been reported as an indication of the fit procedure in Table 1. They correlate very well with literature data on An(IV) carbonates : the crystalline structure of $\mathrm{Pu}\left(\mathrm{CO}_{3}\right)_{5}{ }^{6-}$ locates oxygen atoms at 2.42 $\AA$, carbon atoms at $2.88 \AA^{42}$; the crystalline structure of $\mathrm{Th}\left(\mathrm{CO}_{3}\right)_{5}{ }^{6-}$ locates oxygen atoms at $2.47 \AA$, carbon atoms at $2.98 \AA^{43}$.
To go beyond this qualitative comparison, a $\mathrm{F}^{\mathrm{L}}$ - $\mathrm{Pu}$ model $\left(\mathrm{F}^{\mathrm{L}}=\mathrm{L}\right.$ chain of ferritin as explained below), obtained from classical molecular dynamics (MD) simulations, starting from $\mathrm{Pu}\left(\mathrm{CO}_{3}\right)_{5}{ }^{6-}$ in the presence of ferritin, was performed. Since using an entire Ferritin molecule would be too time consuming for such a simulation, especially in light of the fact that our primary focus is on the local environment around $\mathrm{An}$ atoms $(\mathrm{An}=\mathrm{Th}, \mathrm{Pu})$, we selected single $L$ chain of horse apo-Ferritin (from cadmiumbound Ferritin, PDB:1aew) ${ }^{44}$ and used it as a model for $\mathrm{Pu}(\mathrm{IV})-$ bound Ferritin (noted $\mathrm{F}^{\mathrm{L}}$ here after). The simulation of $\mathrm{F}^{\mathrm{L}}$-Th was not performed. Two types of simulations were undertaken. In one simulation (simulation A), a crystal structure of the $L$ chain was used as an initial structure by replacing six $\mathrm{Cd}$ atoms therein with $\mathrm{Pu}$. In another simulation (simulation $\mathrm{B}$ ), six $\mathrm{Pu}$ atoms were randomly distributed around a metal-free $\mathrm{L}$ chain. Carbonate $\left(\mathrm{CO}_{3}{ }^{2-}\right)$ and $\mathrm{Na}^{+}$ions were further added to mimic experimental carbonate concentrations and for the sake of charge neutralization. Further details of calculations are given in the experimental section. Simulations were performed for $150 \mathrm{~ns}$ simulation time.

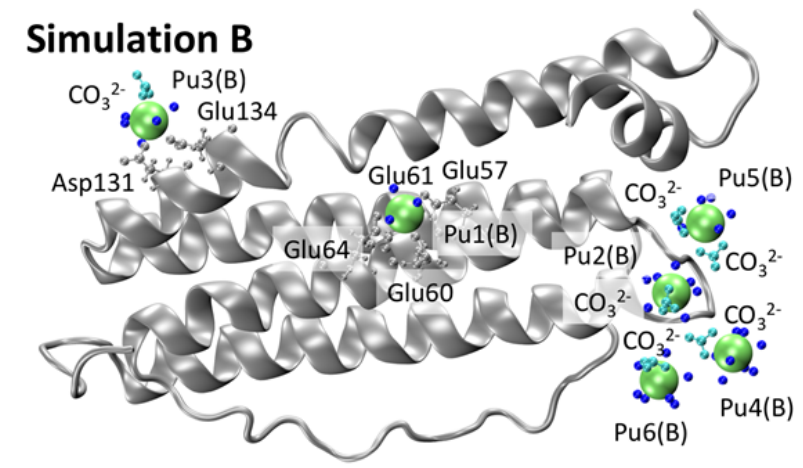

Figure 3. Simulation $B$ model $\left(F^{L}-P u\right)$ : Structures of $P u$-bound $L$ chain at simulation time $t=150 \mathrm{~ns}$. Protein in gray ribbon, $P u$ in large lime balls, waters in small blue balls (hydrogen atoms omitted), carbonate ions in light blue.

The results of MD simulations show that out of $6 \mathrm{Pu}^{4+}$ ions in the simulation box, roughly one third binds to the protein and the rest remains unbound. Both simulations (simulations $A$ and $B$ ) with different initial $\mathrm{Pu}$ positions converged to two structures (Figure 3 and Figure S5ab of $\mathrm{SI}$ ) whereas their binding patterns (e.g. ratio of bound and free $\mathrm{Pu}$, involved amino acids) are overall very similar.

Positions of $\mathrm{Pu}$ atoms in MD trajectories depends heavily on where they were initially placed and the snapshots depicted in Figure 3 and S5 may further develop over longer simulation scale. Therefore, these images should only be seen as conceptual and Pu positions therein should not be considered as their "final positions". Nonethless, closer look into local environment around $\mathrm{Pu}$ gives great hints about the nature of $\mathrm{Pu}$ ferritin interaction. $P u(I V)$ binding to the $L$ chain appears to be non-specific and each Pu has its own environment composed of water, carbonates and carboxylate groups derived from the amino acids of the protein. In simulation $\mathrm{A}$, two $\mathrm{Pu}(\mathrm{IV})$ ions are bound to the protein via one or two carboxylic groups of Asp and Glu. In simulation $\mathrm{B}$, two $\mathrm{Pu}(\mathrm{IV})$ ions are bound to the protein involving two or four carboxylic groups of Asp or Glu. In both simulations $A$ and $B$, the rest of $\mathrm{Pu}$ (which remain unbound to the protein) form carbonate aquo complexes (see Table S5). 
However, it is possible that in present simulations, the presence of unbound $\mathrm{Pu}$ is overrepresented because of too high concentration of metal in simulation box. The average radial distribution functions (RDF) around the $\mathrm{Pu}$ atoms for proteinbound (2 $\mathrm{Pu}$ atoms) and protein-free (4 Pu atoms) Pu are given in Figure S6abc of SI. First Pu coordination sphere emerges at around $2.35 \AA$ with main contributors being oxygens from coordinating protein, waters and carbonate. The second coordination sphere is made of $C$ atoms. It is localized around $2.85 \AA$ and it corresponds to atoms from carbonate anions and protein. A third coordination sphere, characteristic of only $C$ atoms from the protein, is localized around $3.45 \AA$. A detail of this part of the RDF for Pu1(B) and Pu3(B) (both being linked to the protein) is given in insert of Figure S6b. In conclusion, when a ternary complex occurs (Pu3(B)) C from carbonates and protein are visible in the second and third coordination spheres respectively. When a binary complex occurs (Pu1(B)), C from the protein are visible with less intensity in the third coordination sphere. But of course, this is only indicative.

6 EXAFS spectra corresponding to the $6 \mathrm{Pu}$ atoms of simulation $B$ have been calculated (see Figure S7 of SI). The average of Pu1(B) and Pu3(B) (called merge-Pu model in Figure S7 of SI) represents the average EXAFS spectrum of $\mathrm{Pu}$ bound to the protein in Simulation B. Qualitatively, both spectra (merge-Pu and experimental F-Pu) are very similar, except for extra dumping of the amplitude in the $9-11 \AA^{-1}$ region for the F-Pu spectrum. The EXAFS spectrum of the ternary complex Pu3(B) is also compared to that of F-Pu in Figure 2 and again both spectra are very similar.

Based on the environment of the Pu(IV) ions in the $\mathrm{F}^{\mathrm{L}}$-Pu model, EXAFS fitting of F-Pu and F-Th was performed with an environment of carboxylate functions from the protein and possible residual carbonate anion. Best fit parameters of F-Th and F-Pu are displayed in Table 1. The total number of $O$ atoms in the $\mathrm{An}(\mathrm{An}=\mathrm{Th}, \mathrm{Pu})$ first coordination sphere was arbitrarily fixed to 10 because a precise absolute number was difficult to obtain from EXAFS data fitting with such large coordination numbers $(\mathrm{CN})$ ranging from 8 to 12. For F-Pu, Pu-O distances obtained from EXAFS fitting are equal to 2.39(5) $\AA$. This is to be compared with the average value of $2.3-2.5 \AA$ obtained from radial distribution function of Figure $\mathrm{S} 6 \mathrm{ab}$ of $\mathrm{SI}$. In the second coordinating sphere, 5.2(20) $\mathrm{C}$ atoms are located at 3.34(4) $\AA$. This distance corresponds to the largest Pu-C contributions of the RDF (zone 3.3 - $3.5 \AA$ ). No $\mathrm{C}$ atoms around $2.8 \AA$ (corresponding to the second coordination sphere of Pu-C zone in the radial distribution function) were necessary to the fit. Addition in the fit of a fixed triple scattering path corresponding to the distal oxygen atom of a carbonate anion (oxygen that is away from the cation in $\mathrm{CO}_{3}{ }^{2-}$ bindentate binding) did not improve the fit significantly $(Q$ factor $=31$; R-factor $=2.1 \%$ with the triple scattering path of distal $\mathrm{O} ; \mathrm{Q}$ factor $=32$; $\mathrm{R}$-factor $=2.2 \%$ without this contribution). This scattering path is a fingerprint of carbonate ligation in bidentate mode because it is of largest amplitude. In consequence, EXAFS data does not allow to assert whether or not a carbonate anion is present in the $\mathrm{Pu}$ coordination sphere together with protein carboxylates.

The fit of F-Th is similar to that of F-Pu : the Th-O distance is equal to 2.44(6) $\AA$ and the Th-C distance is equal to 3.56(26) $\AA$ (with very large uncertainty). The results of the F-Pu and F-Th complex are very close within the actinidic contraction from Th to $\mathrm{Pu}$. We can therefore deduce that $\mathrm{Pu}$ and Th interact with the ferritin in a similar way.

Further comparison with literature structural data might be provided by the crystallographic plutonium oxalate structure..$^{45}$ In this structure, the $\mathrm{Pu}-\mathrm{O}$ distances range between $2.45 \AA$ and 2.51 $\AA$ and the Pu-C distances range between $3.25 \AA$ and $3.46 \AA$ (but oxalate bonding is quite different). EXAFS best fit (2.39 $\AA$ and $3.42 \AA$ ) for Pu-O and Pu-C respectively are in agreement with those data although the comparison must be only indicative because carboxylate ligands are very different from protein carboxylate functions.

\section{Tentative understanding of $\mathrm{Pu}(\mathrm{Th})$-ferritin interaction}

The load curve of ferritin in the presence of thorium shows that the complexation process occurs until a plateau of $2840 \mathrm{Th}$ atoms per ferritin is reached (corresponding to $\mathrm{Th} / \mathrm{Fe}$ ratio equal to 5.5). Naturally, ferritin can store up to 4500 iron atoms, distributed between the ferrihydric core and its protein ring as follows: up to about 1800 iron atoms in the core and of the order of 2800 iron atoms on the ring. The load curve of stock- $F$ with Th suggest a maximum load of 2840 atoms for one $F$, and this number corresponds to the estimated load of $\mathrm{Fe}$ on the ring of native $F$.

The XANES spectrum at the Fe K edge of F-Th (with Th/Fe ratio equal to 0.5) shows no difference with that of stock- $F$, suggesting that $\mathrm{Fe}$ atoms are mostly located in the core and that no Th is located in their vicinity (XANES probing range less than about $5 \AA$ for $M-M$ interaction). In addition, infrared data of stock$F$ and of $F-T h$ suggest the presence of at least one carbonate anion in the complex. All together, these data back the assumption that a complex might be formed between the ferritin ring, carbonate and Th. In other words, there is no visible interaction between Th and the ferrihydric core, suggesting once again that the majority of Th is complexed on the protein ring. $\mathrm{MD}$ calculations performed with ferritin and $\mathrm{Pu}(\mathrm{IV})$ bring an interesting light to the complexation mechanism. In two types of simulations, the environments at the different $\mathrm{Pu}$ sites support the IR and XANES analysis performed with $\mathrm{Th} / \mathrm{Pu}$ : the cation interacts with the protein ring and forms complexes in which carbonate anions and/or water may also be present. Several types of ternary complexes, composed of carboxylate groups, carbonate and/or water are found to be possible and mixed. EXAFS best fit results of the F-Pu and F-Th spectra also indicate that the local environment of the cation are mainly carboxylate groups but the presence (or absence) of an additional carbonate anion is impossible to assess. In the second sphere 4 to 6 atoms of carbon are located at about 3.4 $\AA$. These carbons correspond to those of the carboxylate groups of the amino acids that make up the ferritin ring. According to the literature, Fe atoms in interaction with the protein ring also have aspartate and glutamate amino acids in their environment. ${ }^{46}$

In the literature, the formation constants of Th with carboxylate groups varies between 4 and 12 (log units) depending on the complex type ${ }^{47}$ while for $\mathrm{Pu}$, constants varies between 8 and 17.48 The formation constant of the $\mathrm{An}\left(\mathrm{CO}_{3}\right) 5^{6-}$ complex is of the order of $62 .{ }^{49} \mathrm{~A}$ simple thermodynamic simulation shows that to displace equilibrium from $\mathrm{Pu}\left(\mathrm{CO}_{3}\right)_{5}^{6-}$ to a $\mathrm{Pu}(\text { Carbox })_{2}$ with a ratio $\mathrm{Pu}\left(\mathrm{CO}_{3}\right)_{5}{ }^{6-}: \mathrm{Pu}(\mathrm{Carbox})_{2}=1: 100$ (this is only indicative), a minimum ratio of $\mathrm{CO}_{3}{ }^{2-}$ : Carbox $=1: 300$ is neeed. In our study, 
the load curve suggest that the interaction between Th and $F$ involves about 2840 complexation sites (for $1 \mathrm{~F}$ ). This number is in qualitative good agreement with simple thermodynamic considerations. The UV-Vis titration of Pu-F with carbonates supports also this idea and when an excess of carbonate is added, the pure plutonium carbonate complex is formed again. However the actual strength (affinity constant) of this interaction has not been quantified because of the absence of specific binding sites on the subunit.

It has been shown that the ring of amino acids (Asp, Glu) interact with $\mathrm{Fe}$ to eventually drive the atoms from the surface of this ring to the ferrihydric core. Conventional MD simulations of $F$ interacting with iron support the hypothesis that the triple channel is the main passage for iron ions from the outside of the ferritin to the ferrihydric core. When a ferrous ion reaches the entrance of the triple channel, it first encounters the histidine residue at the outer opening of the channel. It then spontaneously leaves the histidine site to interact with three residues of Asp and three residues of Glu which serve as binding sites for $\mathrm{Fe}^{2+} / \mathrm{Fe}^{3+}$ within the funnel-shaped triple channel. As more external $\mathrm{Fe}$ ions enter these channels, they are pushed towards the center of the ferritin. ${ }^{50,51}$ The $\mathrm{F}^{\mathrm{L}}$-Pu models together with all spectroscopic data reported here suggest that the same aspartate and glutamate amino acids interact with Th/Pu on the protein ring. Therefore a similar mechanism could be invoked for $\mathrm{Th} / \mathrm{Pu}$ cations because of their affinity for the same carboxylate function. But in present experimental conditions our EXAFS data show no trace of $\mathrm{Th} / \mathrm{Pu}$ on the surface of the ferrihydric core.

Finally, previous studies of iron interactions within mammalian ferritin and bacterioferritins have been performed by $\mathrm{X}$-ray crystallography. Fe has been shown to be located on the inner surfaces of the $L$ chain apoferritin ${ }^{52}$. The residues interacting with $\mathrm{Fe}$ are the carboxylate groups from glutamates and histidines, very similar to our findings with $\mathrm{Pu}$ and $\mathrm{Th} .{ }^{53}$ This also confirms that the interaction sites are not selective for the metal.

\section{Conclusion}

This work explores the interactions of early actinides (Th, Pu) at oxidation state +IV with ferritin $(F)$, an essential iron storage protein, and its ability to store those elements at physiological $\mathrm{pH}$ compared to Fe.

The maximum storage capacity of ferritin with $\mathrm{Th}(\mathrm{IV})$ was determined by measuring the F-Th load curve. It shows a maximum $\mathrm{F} / \mathrm{Th}$ ratio equal to $1 / 2840$. This ratio agrees with the maximum storage capacity of the protein ring with $\mathrm{Fe}$. Comparison of spectroscopic data (spectrophotometry, XAS, FT-IR) together with Molecular Dynamics (MD) calculations suggest also that $\mathrm{Th}(\mathrm{IV})$ and $\mathrm{Pu}(\mathrm{IV})$ are complexed mainly on the protein ring and not on the ferrihydric core. EXAFS best fit data of the F-Pu and F-Th complexes indicate that the local environment of the cation are mainly carboxylate groups. Overall, EXAFS analysis together with MD calculations support the complexation of Th(IV) and Pu(IV) with carboxylated amino acids of the protein ring and a possible additional carbonate anion. It has been shown that the ring of amino acids (Asp, Glu) interact with iron to eventually drive the atoms from the surface of this ring to the ferrihydric core. The MD models together with all spectroscopic and analytical data reported here suggest that the aspartate and glutamate amino acids interact with $\mathrm{Th} / \mathrm{Pu}$ in a similar way $\mathrm{Fe}$ does. This thorough description from a molecular view point of $\mathrm{Th}(\mathrm{IV})$ and $\mathrm{Pu}(\mathrm{IV})$ interaction with ferritin is an important step in comprehensive nuclear toxicology.

\section{Experimental section}

All chemicals used were of analytical grade except for the protein. Horse Spleen Ferritin was purchased from Sigma-Aldrich. The commercial batch was dialyzed prior to use : ferritin was placed in a $12 \mathrm{kDa}$ membrane and dialyzed for 24-hour 3 times in buffer medium $5 \times 10^{-2} \mathrm{M}$ MES, $1.5 \times 10^{-1} \mathrm{M} \mathrm{NaCl}, \mathrm{pH} 7.4 \pm 0.1$.

\section{Actinide (Th, Pu) stock solutions}

${ }^{239} \mathrm{Pu}(96 \% 239,4 \% 240)$ was obtained from CEA stock. This stock solution underwent a step of total reduction to $\mathrm{Pu}$ (III) with a mixture of $0.5 \mathrm{M}$ hydroxylamine $+0.5 \mathrm{M}$ hydrazine in nitric acid medium. ${ }^{54}$ After reoxidation in nitric acid, the solution was purified using a DOWEX $1 / 8$ chlorine ion exchange resin.

$\mathrm{Pu}\left(\mathrm{CO}_{3}\right)_{5}{ }^{6-}$ stock solution was prepared by mixing $120 \mu \mathrm{L}$ of $\mathrm{Pu}(\mathrm{IV})$ at $2.5 \times 10^{-3} \mathrm{M}$ and $180 \mu \mathrm{L}$ of carbonate at $3 \mathrm{M}$. Pu(IV) concentration in the carbonate medium was determined from the absorbance of the $486 \mathrm{~nm}$ peak for which molar extinction coefficient is $66 \mathrm{~L} \cdot \mathrm{mol}-1 . \mathrm{cm}^{-1} .37$

A $0.15 \mathrm{M}$ solution of $\mathrm{Th}(\mathrm{IV})$ nitrate $\left(\mathrm{Th}\left(\mathrm{NO}_{3}\right)_{4} .5 \mathrm{H}_{2} \mathrm{O}\right.$, Sigma Aldrich) was dissolved in a $3 \mathrm{M}$ carbonate solution to obtain a $\mathrm{Th}\left(\mathrm{CO}_{3}\right) 5^{6-}$ solution.

\section{Ferritin characterization}

$250 \mu \mathrm{L}$ of F-stock were digested in $15 \mathrm{~mL}$ polypropylene tubes at room temperature for $48 \mathrm{~h}$ with $1 \mathrm{~mL}$ of $34-37 \% \mathrm{HCl}$ (Plasmapure plus degree, SCP Science) and $1 \mathrm{~mL}$ of $67-70 \% \mathrm{HNO}_{3}$ (Plasmapure plus degree, SCP Science). The digested samples were then evaporated to dryness at $95^{\circ} \mathrm{C}$ using a heating block $(\approx 3 \mathrm{~h})$. Finally, $10 \mathrm{~mL}$ of $2 \% \mathrm{HNO}_{3}$ were added to the tubes and placed in the ultrasonic bath for 3 minutes.

Samples were analyzed by ICP-MS/MS (Agilent 8800, Tokyo, Japan). Detection of $\mathrm{Fe}$ was carried out introducing $\mathrm{He}$ in the collision/reaction cell at a flow rate of $4 \mathrm{~mL} \mathrm{~min} \mathrm{~m}^{-1}$ (on-mass detection ${ }^{56} \mathrm{Fe}=>{ }^{56} \mathrm{Fe}$ ) and setting kinetic energy discrimination (KED) to $5 \mathrm{~V}$. The transitions ${ }^{54} \mathrm{Fe}=>{ }^{54} \mathrm{Fe},{ }^{57} \mathrm{Fe}=>{ }^{57} \mathrm{Fe}$ were also monitored, but only the isotope ${ }^{56} \mathrm{Fe}$ was used to quantify F-stock iron content. Quantification of the F-stock iron content was carried out by resorting to external calibration with standards of $\mathrm{Fe}$ in $\mathrm{HNO}_{3} 2 \%$ prepared from ICP-MS Fe standard solutions (SPEX CertiPrep, Inc.). Operation conditions were daily optimized using a tuning solution.

\section{Ferritin - plutonium complexation, spectrophotometry}

Absorption spectra were recorded over the wavelength region 400-550 nm with a single beam Agilent Cary 60 UVNis spectrophotometer and using a small volume $10 \mathrm{~mm}$ path length quartz cuvette.

The plutonium carbonate-ferritin complex was prepared by mixing $150 \mu \mathrm{L}$ of $\mathrm{Pu}\left(\mathrm{CO}_{3}\right) 5^{6-}$ stock, $[\mathrm{Pu}]=1 \times 10^{-3} \mathrm{M}$, with $150 \mu \mathrm{L}$ of $\mathrm{F}$ in the buffered solution: $5 \times 10^{-2} \mathrm{M} \mathrm{MES}+1.5 \times 10^{-1} \mathrm{M} \mathrm{NaCl}$; $\mathrm{pH}$ $7.4 \pm 0.1$. An addition of $75 \mu \mathrm{LNNO}_{3} 2 \mathrm{M}$ followed by a $50 \mu \mathrm{L}$ addition of the buffer solution maintained the $\mathrm{pH}$ at $7.4 \pm 0.1$. With these conditions, the complex F/Pu ratio was equal to $1 / 2780$. This solution was left to stand for 24 hours.

To reverse complexation equilibrium, $50 \mu \mathrm{L}$ of $3 \mathrm{M}$ carbonate solution were then added directly to the Pu-F complex solution 
and the spectra were recorded successively until the spectrum no longer evolved. This operation was repeated three times. The last spectrum was recorded 72 hours after the last addition.

\section{Ferritin-Thorium load curve}

Different samples were prepared with various ratios of Th : F, from $0: 1$ to $3600: 1$. Each sample was prepared in triplicate for one point of the load curve. For all samples, the same procedure was applied. $25 \mu \mathrm{L}$ of diluted $\mathrm{Th}\left(\mathrm{CO}_{3}\right)_{5}{ }^{6-}$ stock solution, [Th] = $8.2 \times 10^{-3} \mathrm{M}$, were mixed with $250 \mu \mathrm{L}$ of $\mathrm{F}$ previously stored in the buffer medium. The contact was made directly on a $30 \mathrm{kDa}$ microcon ${ }^{\circledR}$ centrifugal filter and stored at $4^{\circ} \mathrm{C}$ during 24 hours. A centrifugation step (12000g; 6 minutes; $4^{\circ} \mathrm{C}$ ) followed by rinsing with the buffer medium was carried out. The supernatant was then recovered (after rinsing of the filter). Supernatants were digested in $15 \mathrm{~mL}$ polypropylene tubes at room temperature for $48 \mathrm{~h}$ with $1 \mathrm{~mL}$ of $34-37 \% \mathrm{HCl}$ (Plasmapure plus degree, SCP Science) and $1 \mathrm{~mL}$ of $67-70 \% \mathrm{HNO}_{3}$ (Plasmapure plus degree, SCP Science). The digested samples were then evaporated to dryness at $95{ }^{\circ} \mathrm{C}$ using a heating block $(\approx 3 \mathrm{~h}$ ). Finally, $10 \mathrm{~mL}$ of $2 \% \mathrm{HNO}_{3}$ were added to the tubes and placed in the ultrasonic bath for 3 minutes. Afterwards, $1 \mathrm{~mL}$ of this solution was diluted to $10 \mathrm{~mL}$ with $2 \% \mathrm{HNO}_{3}$ (Suprapure).

Samples were analyzed by ICP-MS/MS (Agilent 8800, Tokyo, Japan). Simultaneous detection of $\mathrm{Fe}$ and Th was carried out introducing $\mathrm{He}$ in the collision/reaction cell at a flow rate of $4 \mathrm{~mL}$ min-1 and KED = 5V (on-mass detection ${ }^{56} \mathrm{Fe}=>{ }^{56} \mathrm{Fe}$ and ${ }^{232} \mathrm{Th}$ $\Rightarrow{ }^{232} \mathrm{Th}$ for $\mathrm{Fe}$ and $\mathrm{Th}$, respectively). The transitions ${ }^{54} \mathrm{Fe}=>{ }^{54} \mathrm{Fe}$, ${ }^{57} \mathrm{Fe}=>{ }^{57} \mathrm{Fe}$ were also monitored, but only the isotope ${ }^{56} \mathrm{Fe}$ was used to determine the $\mathrm{Th} / \mathrm{Fe}$ ratio. Operation conditions were daily optimized using a tuning solution. Determination of the $\mathrm{Th} / \mathrm{Fe}$ molar ratios were carried out by resorting to external calibration with standards of Th and Fe prepared from single element ICP-MS standard solutions (SPEX CertiPrep, Inc.). Solutions with constant $\mathrm{Fe}$ concentration (equal to that in the samples) and increasing Th concentration were prepared in $\mathrm{HNO}_{3} 2 \%$, resulting in a range $\mathrm{Th} / \mathrm{Fe}$ from 0 to 3.4 .

An analytical blank consisting of thorium carbonate in protein-free MES was prepared in the same conditions. In the filtrate of this sample $99 \%$ of initial Th was measured, showing that the filter does not adsorb Th.

\section{Ferritin-plutonium MD simulation}

MD simulations were performed using AMBER 15 program package ${ }^{55}$ with ff99SB force field applied on the protein. For $\mathrm{Pu}^{4+}$, 12-6-4 LJ-type parameters developed by Merz et al. have been employed $^{56}$. For carbonate ions, additional parameters have been employed ${ }^{57}$. Protonation state of the protein was adjusted to model $\mathrm{pH} 7.4$. $\mathrm{Na}^{+}$ions were added to make the system electrostatically neutral. TIP3P waters were then added with minimum water layer thickness of $10 \AA .500$ steps of steepest decent and 500 steps of conjugate gradient with $500 \mathrm{kcal} \mathrm{mol}^{-1} \AA^{-}$ ${ }^{1}$ harmonic restraint on the protein was initially conducted after which 1000 steps of steepest decent and 1500 steps of conjugate gradient were performed without constraints. 40 ps of heating of the system from 0 to $298 \mathrm{~K}$ with $10 \mathrm{kcal} \mathrm{mol}^{-1} \AA^{-1}$ harmonic restraint on the protein, after which another $1 \mathrm{~ns}$ preconditioning run was performed at $298 \mathrm{~K}$ without restraint on the solutes. Finally, $150 \mathrm{~ns}$ MD run was performed in a periodic boundary condition in NPT ensemble at $298 \mathrm{~K}$. Simulations were terminated and restarted every $5 \mathrm{~ns}$ to avoid artificial convergence to a particular geometry. The SHAKE algorithm, a 2 fs time integration step, $12 \AA$ cutoff for non-bonded interactions, and the particle mesh Ewald (PME) method were used. MD trajectory was recorded at each $50 \mathrm{ps.} \mathrm{Simulations} \mathrm{were}$ performed with two different initial structures (simulations $A$ and B) for $150 \mathrm{~ns} M D$ simulation time. For both simulations, the positions of $6 \mathrm{Pu}$ atoms relative to that of the protein reached equilibrium at around the middle of $150 \mathrm{~ns}$ simulation. Therefore, the last $75 \mathrm{~ns}$ MD trajectory was used for statistical sampling to ensure the equilibrated structures. RMSD of both simulations are given in Figure S8 in SI of the Electronic Supporting Information.

\section{Th IR spectroscopy}

ATR-FTIR spectra were recorded on a Bruker Tensor 27 instrument by using a nitrogen cooled mercury cadmium telluride (MCT) detector. A six-reflection diamond crystal was used as the refection unit.

Diluted $\mathrm{Th}\left(\mathrm{CO}_{3}\right)_{5}{ }^{6-}$ stock solution, $[\mathrm{Th}]=5.5 \times 10^{-2} \mathrm{M}$, was prepared. The thorium carbonate-ferritin complex was prepared by mixing $25 \mu \mathrm{L}$ of $\mathrm{Th}\left(\mathrm{CO}_{3}\right) 5^{6-}$ stock with $200 \mu \mathrm{L}$ of $\mathrm{F}$ in a buffered solution: $5 \times 10^{-2} \mathrm{M}$ MES $+1.5 .10^{-1} \mathrm{M} \mathrm{NaCl} ; \mathrm{pH} 7.4 \pm 0.1$. The contact was made directly on a $30 \mathrm{kDa}$ microcon $\AA$ centrifugal filter and stored at $4^{\circ} \mathrm{C}$ during 6 hours. A centrifugation step (12 $000 \mathrm{~g} ; 6$ minutes; $4^{\circ} \mathrm{C}$ ) followed by rinsing with the buffer medium was carried out. The sample was then recovered on the filter. Final sample volume was $250 \mu \mathrm{L}$ and the complex F/Th ratio was equal to $1 / 2890.50 \mu \mathrm{L}$ were placed in micro-volume cell directly placed on the crystal.

Spectra were acquired with $4 \mathrm{~cm}^{-1}$ resolution and 1024 scans were averaged for each sample. The slit opening for the incident beam was optimized at $3 \mathrm{~mm}$.

\section{Fe, Th and Pu XAS measurements}

$35 \mu \mathrm{L}$ of $\mathrm{Pu}\left(\mathrm{CO}_{3}\right) 5^{6-}$ stock solution, $[\mathrm{Pu}]=2 \times 10^{-3} \mathrm{M}$, was mixed to $250 \mu \mathrm{L}$ of $\mathrm{F}$ in a buffered solution: $5 \times 10^{-2} \mathrm{M}$ MES $+1.5 \times 10^{-1} \mathrm{M}$ $\mathrm{NaCl} ; \mathrm{pH} 7.4 \pm 0.1$. The contact was made directly on a $30 \mathrm{kDa}$ microcon $\circledast$ centrifugal filter and stored at $4^{\circ} \mathrm{C}$ during 6 hours. A centrifugation step (12000g; 6 minutes; $4^{\circ} \mathrm{C}$ ) followed by rinsing with the buffer medium was carried out. The sample was then recovered on the filter. Final sample volume is $250 \mu \mathrm{L}$. The complex F/Pu ratio is equal to $1 / 550$.

$25 \mu \mathrm{L}$ of diluted $\mathrm{Th}\left(\mathrm{CO}_{3}\right) 5^{6-}$ stock solution, $[\mathrm{Th}]=7.1 \times 10^{-3} \mathrm{M}$, was mixed with $250 \mu \mathrm{L}$ of $\mathrm{F}$ in a buffered solution: $5 \times 10^{-2} \mathrm{M}$ MES + $1.5 \times 10^{-1} \mathrm{M} \mathrm{NaCl} ; \mathrm{pH} 7.4 \pm 0.1$. The contact was made directly on a $30 \mathrm{kDa}$ microcon $®$ centrifugal filter and stored at $4^{\circ} \mathrm{C}$ during 6 hours. A centrifugation step $\left(12000 \mathrm{~g} ; 6\right.$ minutes; $4^{\circ} \mathrm{C}$ ) followed by rinsing with the buffer medium was carried out. The sample was then recovered on the filter. Final sample volume is $250 \mu \mathrm{L}$. The complex F/Th ratio is equal to $1 / 1973$.

XAS experiments were carried out on the MARS beamline at the SOLEIL synchrotron facility which is dedicated to the study of radioactive materials. The optics of the beamline consisted of a water-cooled double-crystal monochromator for incident energy selection and horizontal focalization, and two large water-cooled reflecting mirrors for high-energy rejection (harmonic part) and vertical collimation and focalization. All the measurements were recorded in double-layered solution cells $(200 \mu \mathrm{L})$ specifically designed for radioactive samples at room temperature. 
XAS data were acquired at the Th $\mathrm{L}_{\text {III }}$ edge (16 $\left.300 \mathrm{eV}\right)$, at the $\mathrm{Pu} \mathrm{L}_{\text {III }}$ edge (18 $057 \mathrm{eV}$ ) and at the Fe K edge (7 112 eV) (0.5 eV/step for Fe XANES).

Data were processed by using the ATHENA code of Demeter 0.9 .25 package. ${ }^{58}$

EXAFS data were adjusted using phases and amplitudes calculated with Feff7 code embedded in ARTEMIS code of Demeter 0.9.25. The site of Pu3(B) obtained in the above MD B calculations was used as a model. EXAFS signal was fitted in $R$ space between 1 and $6 \AA$ without any additional filtering after Fourier transformation using a Hanning windows in $\mathrm{k}^{2}$ (2.7 - 10.8 $\left.\AA^{-1}\right)$. In all the fits, only one global amplitude factor $S_{0}^{2}$ and one energy threshold $e_{0}$ factor were considered for all the contributions. The agreement factor $\mathrm{R}$ (in \%) and quality factor reduced $\chi^{2}(Q)$ are both provided as an indication of the fit quality. Simulation of the $6 \mathrm{Pu}$ centers obtained from simulation B of MD were performed with Feff9 code using an energy threshold of 8 eV.

\section{Acknowledgements}

All MD calculations were performed at Zentrum für Informationdienste und Hochleistungrechnen of Technische Universität Dresden, Germany. Generous allocation of computing time is gratefully appreciated.

XAS data were collected at the MARS beam line of SOLEIL synchrotron, Gif sur Yvette, France.

PhD fellowship of C. Zurita was provided by the Ministry of Higher Education and Research, France. 
WILEY-VCH

\section{FULL PAPER}

\section{Entry for the Table of Contents}
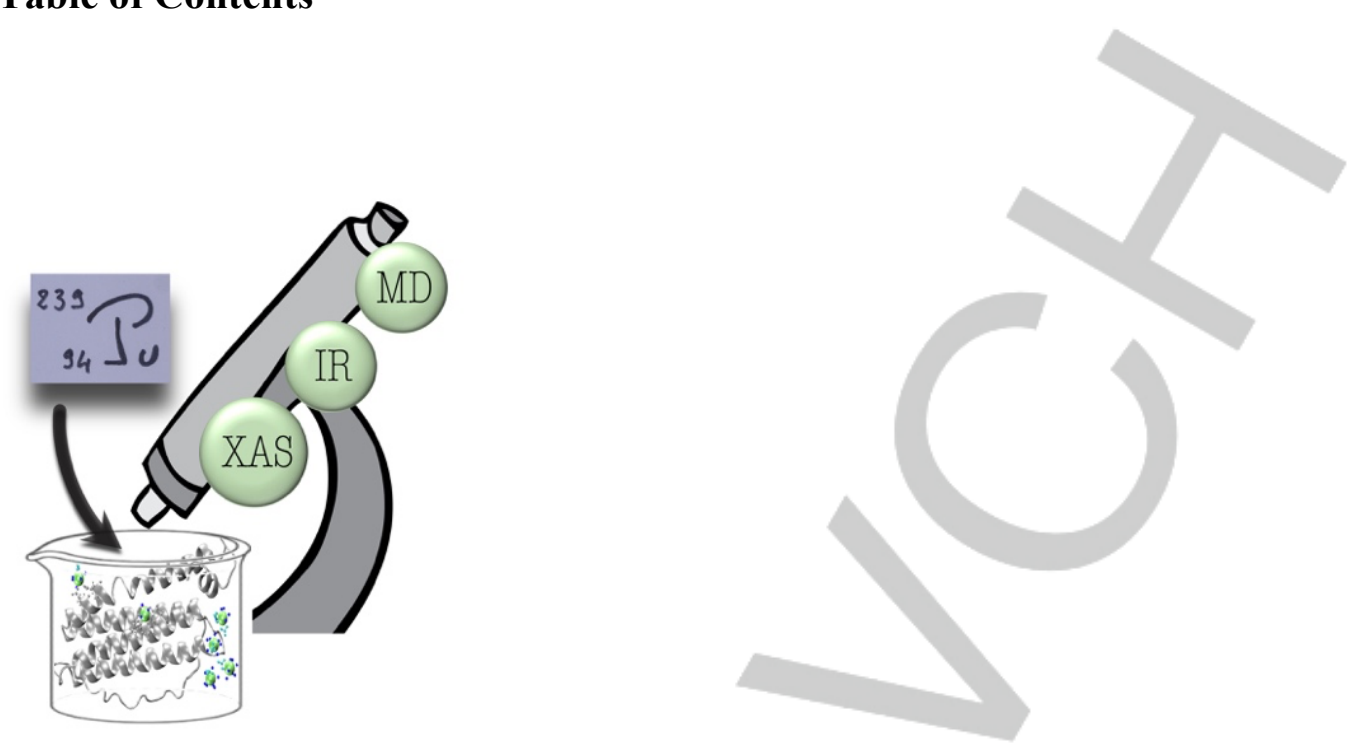

With a tool box of analytical, spectroscopic and molecular dynamic techniques, this work sheds light on the interactions of plutonium (and thorium), early actinides at oxidation state $+\mathrm{IV}$, with ferritin and its ability to store those elements at physiological $\mathrm{pH}$ compared to $\mathrm{Fe}$.

Institute and/or researcher Twitter usernames:

1 National Council on Radiation Protection and Measurements. Management of Persons Contaminated with Radionuclides Handbook: Recommendations of the National Council on Radiation Protection and Measurements, Bethesda, MD, USA, 2009.

2 P. W. Durbin, The Chemistry of the Actinide and Transactinide Elements (Eds.: L. R. Morse, N. M. Edelstein, J. Fuger), Springer, Dordrecht, 2011, 3339-3440.

${ }^{3}$ E. Ansoborlo, O. Prat, P. Moisy, C. Den Auwer, P. Guilbaud, M. Carriere, B. Gouget, J. Duffield, D. Doizi, T. Vercouter, Biochimie, 2006, 88, 1605-1618.

${ }^{4}$ A.E.V. Gorden, J. Xu, K.N. Raymond, P. Durbin, Chem. Rev., 2003, 103, 4207-4282.

${ }^{5}$ P. W. Durbin, Health Phys. 1962, 8, 665-671.

${ }^{6}$ B. Ramounet, S. Matton, G. Grillon, P. Fritsch, J. Alloys Comp., 1998, 271-273.

${ }^{7}$ E. Ansoborlo, O. Prat, P. Moisy, C. Den Auwer, P. Guilbaud, M. Carriere, B. Gouget, J. Duffield, D. Doizi, T. Vercouter, C. Moulin, V. Moulin, Biochimie, 2006, 88, 1605-1618.

${ }^{8}$ M. Fouillit, G. Grillon, P. Fritsch, G. Rateau, D. Pavé, J. Delforge, B. Le Gall, Int. J. Radiat. Biol. 2004, 80, 683689.

9 International Commission on Radiological Protection, Individual monitoring for internal exposure of workers, ICRP Publication 78, Ann.ICRP 27(3-4), Elsevier, Oxford, 1998.

10 International Commission on Radiological Protection, Age-dependent Doses to Members of the Public from Intake of Radionuclides: Part 3, ICRP Publication 69, Ann. ICRP 25 (1), Elsevier, Oxford, 1995.

11 G.R. Choppin, Radiochim. Acta, 1983, 32, 43-53.

12 D.L. Clark, S.S. Hecker, G.D. Jarvinen, M.P. Neu, The Chemistry of the Actinide and Transactinide Elements Vol. 2 (eds. Morss, L.R., Edelstein, N.M. \& Fuger, J.), 2006, 813-1264.

${ }^{13}$ B. Allard, H. Kipatsi, J.O. Liljenzin, J. Inorg. Nucl. Chem., 1980, 42, 1015-1027.

${ }^{14}$ M.L. Kennard, D.R. Richardson, W.A. Jefferies and P. Ponka, The EMBO Journal, 1995, 14-17, 4178-4186.

${ }^{15}$ P.M. May, D.R. Williams, P.W. Linder, (ed Sigel, H.), Metal lons in Biological Systems. Marcel Dekker Inc., NY, 1980, 29-76.

${ }^{16}$ G. Boocock, D.S. Popplewell, Nature, 1965, 208, 282-283.

17 D.M. Taylor, J. Alloy. Compd., 1998, 271, 6-10.

${ }^{18}$ M. P. Jensen, D. Gorman-Lewis, B. Aryal, T. Paunesku, S. Vogt, P. G. Rickert, S. Seifert, B. Lai, G. E. Woloschak, L. Soderholm, Nature Chem. Biol. 2011, 7, 560-565. 
19 J.R. Duffield, D.M Taylor, Handbook on the Physics and Chemistry of the Actinides Vol. 4 (eds. Freeman, A.J. \& Keller, C.), 1986, 129-157.

20 G. Boocock, C.J. Danpure, D.S Popplewell, D.M. Taylor, Radiat. Res., 1970, 42, 381-396.

${ }^{21}$ B. J. Stover, F. W. Bruenger, W. Stevens, Research in Radiobiology, University of Utah College of Medecine, USA, 1970, 131-144

22 D. M. Taylor, G. J. Kontoghiorghes, Inorg. Chim. Acta 1986, 125, L35-L38.

${ }^{23}$ A. Mazur, S. Green, A. Carleton, J. Biol. Chem. 1960, 235, 595-603.

${ }^{24}$ A. Jacobs, F. Miller, M. Worwood, M. Beamish, C. Wardrop, Br. Med. J., 1972, 206-208.

${ }^{25}$ N.D. Chasteen, P.M. Harrison, J. Struct. Biol., 1999,126,182-94.

${ }^{26}$ A. Lewin, G.R. Moore, N.E. Le Brun, Dalton Trans., 2005, 3597-3610.

${ }_{27}$ P. Arosio, T.G. Adelman, J.W. Drysdale, J. Biol. Chem., 1978, 253, 4451.

${ }^{28}$ P.M. Harrison, P. Arosio, Biochim. Biophys. Acta Bioenerg., 1996, 161-203.

${ }^{29}$ P.D. Hempstead, S.J. Yewdall, A.R. Fernie, D.M. Lawson, P.J. Artymiuk, D.W. Rice, G.C. Ford, P.M. Harrison, J. Mol. Biol., 1997, 268, 424-448.

${ }^{30}$ P. Arosio, M. Yokota, J.W. Drysdale, Cancer. Res., 1976, 36, 1735-1739.

31 T. Tosha, H.-L. Ng, O. Bhattasali, T. Alber, E.C. Theil, J. Am. Chem. Soc., 2010, 132, 14562-14569.

${ }^{32}$ P. Rucker, F. M. Torti, S. V. Torti, J. Biol. Chem., 1996, 271, 33352-33357.

${ }^{33}$ S. Kumar, G. Creff, C. Hennig, A. Rossberg, R. Steudtner, J. Raff, C. Vidaud, F. R. Oberhaensli, M-Y Dechraoui Bottein, C. Den Auwer, Chem. Eur. J., 2019, 25, 12332-12341.

${ }^{34}$ P. Astrup, J. Clin. \& Lab. Investigations, 1956, 8, 33-43.

${ }^{35}$ G. Jutz, P. van Rijn, B. S. Miranda, A Böker, Chem. Rev., 2015, 115, 1653-1701.

${ }^{36}$ Y.H. Pan, K. Sader, J. J. Powell, A. Bleloch, M. Gass, J. Trinick, A. Warley, A. Li, R. Brydson, A. Brown, J. Structural Biology, 2009, 106, 22-31.

${ }^{37}$ H. Capdevilla, P. Vitorge, E. Giffaut, L. Delmau, Radiochimica Acta, 1996, 74, 93-98.

38 K. Nakamoto, Infrared and Raman Spectra of Inorganic and Coordination Compounds, J. Wiley \& Sons, Inc.: New York, 1986.

${ }^{39}$ K. Ito, J.H. Bernstein, Can. J. Chem., 1956, 34, 170-178.

40 J.P. Jolivet, Y. Thomas, B. Taravel, V. Lorenzelli, G. Busca, J. Mol. Struct., 1982, 403-408.

${ }^{41}$ T. Hiemstra, R. Rahnemaie, W.H. Riemsdjik, J. Coll. Inter. Science, 2004, 282-290.

${ }^{42}$ D. L. Clark, D. E. Hobart, M. P. Neu, Chem. Rev., 1995, 95, 25-48.

${ }^{43}$ S. Voliotis, A. Rimsky, Acta. Cryst., 1975, 2615-2620.

${ }^{44}$ P.D. Hempstead, S.J. Yewdall, A.R. Fernie, D.M. Lawson, P.J. Artymiuk, D.W. Rice, G.C. Ford, P.M. Harrison, J. Mol. Biol., 1997, 268(2), 424-448.

${ }^{45}$ W. Runde, L.F. Brodnax, G. Goff, A.C. Bean, B.L. Scott, Inorg. Chem., 2009, 48, 5967-5972.

${ }^{46}$ R. Laghaei, D.G. Evans, R.D. Coalson, Proteins: Struct., Funct., Bioinf., 2013, 81, 1042-1050.

47 L. Rao, P. Zaonato, P. Di Bernardo, J. Nucl. Radiochem. Sci., 2005, 31-37.

${ }^{48}$ P. Thakur, P.N. Pathak, G.R. Choppin, Inorg. Chim. Acta, 2009, 179-184.

49 J.I. Kim, C. Lierse, F. Baugartner, ACS Symposium Series, 1983, Vol. 216, 317-334.

50 A.Crow, T.L. Lawson, A. Lewin, G.R. Moore, N.E. Le Brun, J. Am. Chem. Soc., 2009, 131, 6808-6813.

${ }^{51}$ S.K. Weeratunga, S. Lovell, H. Yao,K.P. Battaille, C.J. Fischer, E.G. Casey, M. Rivera, Biochemistry, 2010, 49, 1160-1175.

52 J.D. Lopez-Castro, J.J. Delgado, J.A Perez-Omil, N. Galvez, R. Cuesta, R.K. Watt, J.M. Dominguez-Vera, Dalton Trans., 2012, 41, 1320-1324

${ }_{53}^{5}$ M.A. Carrondo, The EMBO Journal, 2003, 22 (9), 1959-1968

${ }^{54}$ G.L. Richardson, J.L. Swanson, Plutonium partitioning in the purex process with hydrazine-stabilized hydroxylamine nitrate, Hanford Engineering Development Laboratory, WA, USA, 1975.

${ }_{55}$ D.A. Case, J.T. Berryman, R.M. Betz, D.S. Cerutti, T.E. Cheatham, III, T.A. Darden, R.E. Duke, T.J. Giese,H. Gohlke, A.W. Goetz, N. Homeyer, S. Izadi, P. Janowski, J. Kaus, A. Kovalenko, T.S. Lee, S. LeGrand,P. Li, T. Luchko, R. Luo, B. Madej, K.M. Merz, G. Monard, P. Needham, H. Nguyen, H.T. Nguyen, I. Omelyan, A. Onufriev, D.R. Roe, A. Roitberg, R. Salomon-Ferrer, C.L. Simmerling, W. Smith, J. Swails, R.C. Walker, J. Wang, R.M. Wolf, X. Wu, D.M. York and P.A. Kollman, 2015, AMBER 2015, University of California, San Francisco.

${ }^{56}$ P. Li, L.F. Song, K.M. Merz, Jr. J. Phys. Chem. B, 2015, 119, 883-895.

${ }^{57}$ S.Kerisit, C.Liu, Environ Sci. Technol., 2014, 48 (7), 3899-3907.

${ }^{58}$ B. Ravel, M. Newville, J. Synch. Rad., 2005, 12, 537-541. 